\title{
Ranchers manage land to enhance watershed
}

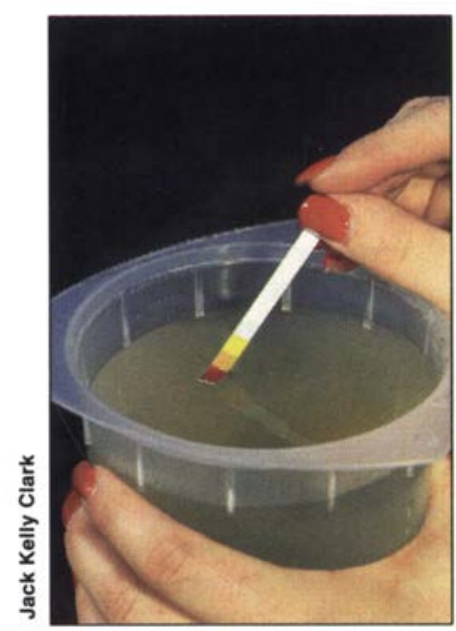

Measuring pH and temperature helps determine the level of ammonia in water. At a certain level, ammonia becomes toxic to fish.

\section{A}

gricultural landowners in Marin and

Sonoma counties have begun developing "ranch plans" that will enable them to meet water quality standards established by the Clean Water Act and state and local agencies.

"The plans are voluntary," says UCCE livestock advisor Stephanie Larson, "but if you're cited for a spill or a problem area is found, having a plan in hand shows your willingness to cooperate with regulators. Not having a plan means regulators are probably going to come down harder in the form of a fine."

Although the Clean Water Act has been in place for 20 years, regulators have only recently shifted their focus from point-source to nonpoint-source pollution (pollution which results from diffuse discharges throughout the environment).

This change has implications for agriculture. In fact, says Marin and Sonoma counties' extension director Ellen Rilla, "The Environmental Protection Agency (EPA) believes that agriculture is the primary nonpoint-source of pollution."

Recent amendments to federal water quality laws have prompted the Regional Water Quality Control Boards to begin regulating nonpoint-source pollution on rangelands unless landowners voluntarily improve water quality.

In addition, the U.S. Fish and Wildlife Service is poised to list spring run steelhead salmon as "endangered" in April. These salmon spawn in virtually all Marin and Sonoma county streams, making water quality an even higher priority.

With forces such as these bringing matters to a head, Marin County Cooperative Extension and other agencies launched the Marin Coastal Watershed Enhancement Project in 1994. Agricultural producers, government regulators, and UCCE specialists and advisors began improving management practices to alleviate both pointsource and nonpoint-source pollution.

The Marin Coastal Watershed Enhancement Project is funded by the Marin Community Foundation, and involves the collaborative efforts of a respected local livestock producer hired by UCCE, the Natural Resource Conservation Service, Point Reyes National Seashore, Marin Agricultural Land Trust, and the Marin
County Resource Conservation District. The project goals include improving water quality, fish habitat and natural resources in western Marin County through voluntary adoption of appropriate management practices.

Marin County's watersheds comprise 232 square miles. Virtually all of that acreage is devoted to dairy and livestock ranching. Because of the high concentration of dairies, animal waste is the greatest pollution concern. Dairy waste in Tomales Bay may damage shellfish production, a $\$ 2$ million industry. "Any $E$. coli from fecal matter could contaminate commercial oyster beds," Larson explains.

Sediment is considered the primary form of nonpoint-source pollution from rangelands. Grazing animals in riparian areas can cause streambank erosion and sedimentation. The practice can also allow nutrients and pathogens to get into waterways. ("Nutrients" such as the nitrogen present in manure can lead to toxic conditions for fish.)

During the summer of 1994 , members of the project met with 54 beef, sheep and dairy operators to discuss the types of resources they felt ranchers needed to improve water quality.

To develop a ranch plan, the advisors helped the ranchers identify potential and actual water quality problems - such as cows drinking out of the creek or feeding next to it, where their manure might be carried into the creek - and the ranch management changes necessary to fix or avert problems. Ranch plans can also help ranchers obtain cost share funding for management practices, i.e. fencing, water development, stream bank restoration.

The project was well-received. Representatives from 25 of about 100 Marin County ranches attended the 6-week, ranch-planning workshop in 1994. Workshops are being offered again this year and include Sonoma County landowners.

UC Davis student Betsy Martin attended the workshop in 1994 and is developing a ranch plan for her parents' dairy in Two Rock, just north of the Marin County border. Martin, who is majoring in agricultural systems and the environment, got involved in conservation planning as a member of Future Farmers of America 
(FFA) in 1993. Participating in the Marin Coastal Watershed Enhancement Project workshops, Martin learned how to control erosion and provide wildlife, habitat along Stemple Creek, which cuts through the dairy, without losing grazing land. Her water quality project earned Martin a statewide Agriscience Student of the Year award and national FFA awards.

"I was trying to control erosion and, in the process, I was hoping to provide quail habitat," Martin says. "Planting trees to control erosion also gives the quail cover and a place to roost away from predators."

During this time, The Department of Fish and Game cited the dairy for dairy waste pollution, which was later traced to an area where manure had been stockpiled. Alerted to the problem, Martin expanded her project. She and her father Paul fenced off the creek and built a bridge and gates to control the animals' movement in and out of the water, then began monitoring the water quality where the creek entered the property and where it left.

By moving cows away from streambanks and allowing vegetation to grow, Martin was able to stabilize the banks. She also teamed up with the Shrimp Club from Brookside Elementary School in San Anselmo, which was trying to save the endangered freshwater shrimp in Stemple Creek. The urban schoolchildren planted native grasses, trees and shrubs to restore the streambank.
"I tested total ammonia, dissolved oxygen, sediment, temperature and $\mathrm{pH}$," she says, "and the water was better leaving [than when entering the property]."

"I think we're moving in the right direction by temporarily excluding animals from the creek," Martin says.

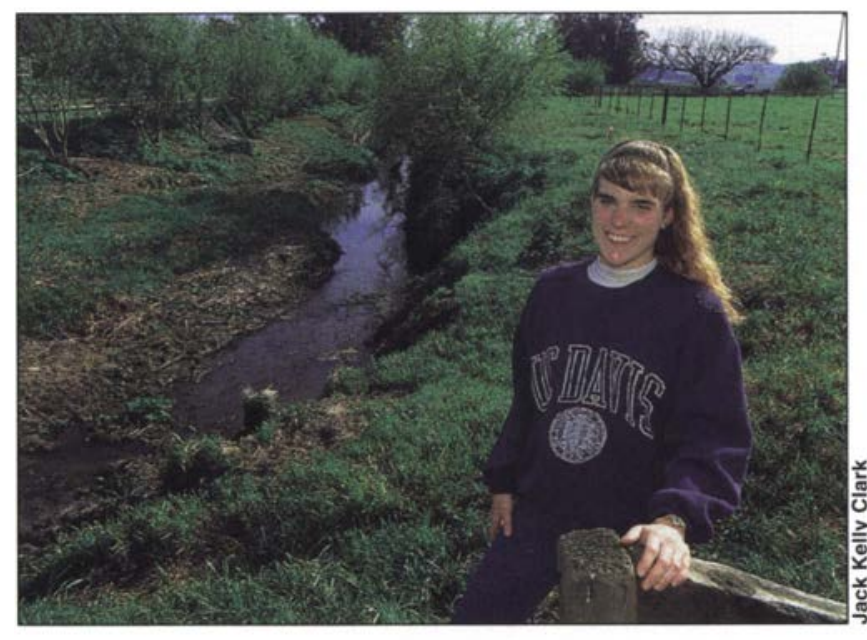

"And, we have an intensely managed grazing system; they're not just running out to eat whatever they want. Now we turn them out until the grass is grazed down to a level where the plants can come back at a reasonable rate."

Larson and Rilla produced a video, a ranch plan workbook and a creek care guide to monitor water quality. Martin can be seen demonstrating water testing in the watershed planning video, "Downstream." The video, ranch plan workbook and creek care guide are available from Stephanie Larson at the Cooperative Extension office, 2604 Ventura Ave., Rm. 100, Santa Rosa, CA 95403.

- Editor

\begin{abstract}
UC Davis student Betsy Martin leans against a fence she built to keep grazing cows away from Stemple Creek. Behind her are willows she and the Shrimp Club planted along the creek to control erosion and to restore the habitat of freshwater shrimp.
\end{abstract}

\section{Research update}

\section{UC scientists seek to ensure safe meat}

Ceveral well-publicized outbreaks of food$\checkmark$ poisoning have many Americans wondering about the safety of their food supply. The most recent incident involved Odwalla brand unpasteurized apple juice, which was linked to 66 cases of intestinal illness and the death of a 16month-old Colorado girl. In Japan, a food-poisoning outbreak beginning in July 1996 killed 11 people and sickened more than 9,000 others.

The cause of both outbreaks was Escherichia coli O157:H7, a toxin-producing strain of a common intestinal bacterium. It causes bloody diarrhea and, in severe cases, kidney failure. First identified in 1982, E. coli O157:H7 was also the culprit in a 1993 food-poisoning outbreak, when four children died and hundreds of people became ill in the Pacific Northwest after eating contaminated fast-food hamburgers. That incident spurred a major reform of federal food safety regulations. The new food safety rules, issued in July 1996, were designed to reduce the risk of illness caused by bacterial contamination of meat and poultry products.

The Centers for Disease Control and Prevention estimate that as many as 5 million people become ill and 4,000 die annually from consuming meat and poultry products contaminated with four major bacterial pathogens: Salmonella, 